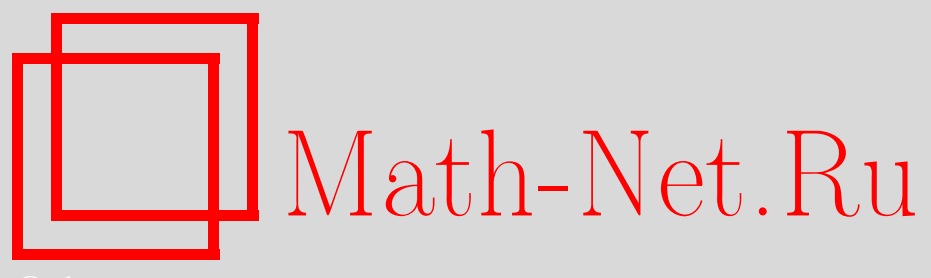

Ю. С. Осипов, Л. Д. Фаддеев, Сергей Петрович Новиков (к семидесятилетию со дня рождения), УМН, 2008, том 63, выпуск 2, 3-4

DOI: https://doi.org/10.4213/rm9194

Использование Общероссийского математического портала Math-Net.Ru подразумевает, что вы прочитали и согласны с пользовательским соглашением http://www.mathnet.ru/rus/agreement

Параметры загрузки:

IP : 3.93.64.190

26 апреля 2023 г., 02:37:56

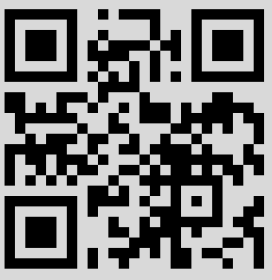




\title{
Сергей Петрович Новиков
}

\author{
(к семидесятилетию со дня рождения)
}

\section{Дорогой Сергей Петрович!}

Работы, выполненные Вами еще в студенческие годы, сразу же поставили Вас в ряд ведущих алгебраических топологов. В них ярко выразился Ваш талант в выборе направлений научных исследований, которым предстояла долгая плодотворная жизнь. В одной из этих работ были открыты фундаментальные свойства когомологий алгебр Хопфа, объекта, не только важного для топологии, но и, как оказалось впоследствии, центрального для теории квантовых групп. Другая работа того же периода заложила основы теории комплексных кобордизмов, которая заняла центральное место в современной алгебраической топологии, во многом благодаря дальнейшим Вашим работам и работам Ваших учеников.

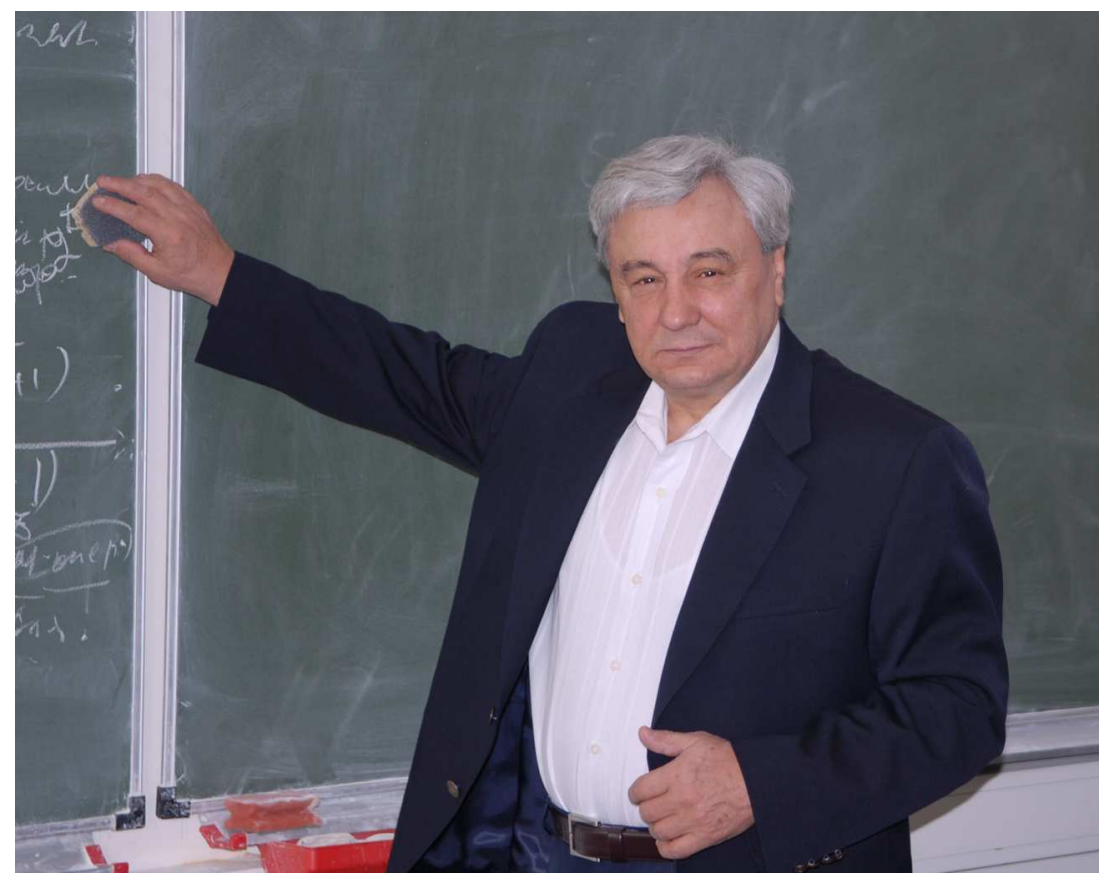

Ваш результат по качественной топологической теории слоений выдвинул Вас на ведущее место и в этой области исследований. Среди Ваших основных топологических результатов - классификация односвязных многообразий размерности больше четырех и доказательство топологической инвариантности рациональных классов Понтрягина. Оба эти результата стали классическими, а идеи и методы, развитые для их получения, оказались прорывными, на них опирается теория перестроек многообразий и решение задач, связанных непрерывными гомеоморфизмами многообразий. 
Вам принадлежат результаты в области периодических задач теории солитонов, открытие связи римановой геометрии и систем гидродинамического типа.

В современную математику вошли: теорема Милнора-Новикова, теорема Новикова о компактном слое, теорема Новикова о неразрешимости проблемы распознавания сферы размерности больше 4, теория Браудера-Новикова, спектральная последовательность и операторы Адамса-Новикова, алгебра Ландвебера-Новикова и новиковские операторные дубли, гипотеза Новикова о высших сигнатурах, ставшая одной из самых известных и плодотворных в алгебраической топологии, гипотеза Новикова, уже приведшая к решению проблемы Римана-Шоттки, теория Морса-Новикова, кольца Новикова и новиковские неравенства для числа критических точек, модель Весса-Зумино-Новикова-Виттена в квантовой теории поля, скобки Дубровина-Новикова в теории гидродинамических систем, иерархия Новикова-Веселова, алгебры и базисы Кричевера-Новикова.

Среди Ваших физических результатов - решение однородных космологических моделей, топологическое квантование констант связи в квантовой теории поля, открытие топологических явлений в нормальных металлах, классификация тензоров проводимости и открытие новых наблюдаемых целочисленных величин. В настоящее время Вы активно развиваете теорию дискретных систем и дискретный комплексный анализ на основе взаимодействия фундаментальных идей математики и физики.

Ваши научные достижения отмечены избранием действительным членом Академии наук СССР, Ленинской премией, Филдсовской медалью Международного математического союза, Международной премией им. Н. И. Лобачевского АН СССР, премией Вольфа, премией Московского математического общества. Вы избраны членом ряда зарубежных академий и обществ, среди которых Лондонское математическое общество, Академия наук и искусств Сербии, Итальянская "Accademia dei Lincei", Европейская Академия, Национальная академия наук США, Папская академия Ватикана.

Вы - создатель и признанный глава обширной научной школы, известной своими достижениями и в стране, и за рубежом. В числе представителей этой школы членыкорреспонденты РАН, десятки профессоров, докторов и кандидатов наук, некоторые из которых в свою очередь стали выдающимися учеными и достигли мировой известности.

Ваши энциклопедические статьи и книги оказали существенное влияние на формирование современных точек зрения на актуальные направления исследований в ряде разделов математики и физики. Многообразна Ваша педагогическая и научно-организационная деятельность. На протяжении многих лет Вы возглавляете кафедру геометрии и топологии на механико-математическом факультете МГУ и одноименный отдел в Математическом институте им. В.А. Стеклова РАН. Ваши учебники и монографии - общепризнанная обязательная часть подготовки современных геометров, топологов, физиков. Ваш вклад в создание программ образования на механико-математическом факультете МГУ, многолетняя работа на посту Президента Московского математического общества, Ваша деятельность как главного редактора журнала "Успехи математических наук", как одного из основателей и члена Научного совета Независимого Московского университета оказали большое влияние на математическую жизнь в России.

Мы высоко ценим широту Ваших познаний, в том числе и в областях, далеких от математики, Вашу принципиальную общественно-научную позицию, выраженную в Ваших выступлениях на заседаниях Академии наук и в Ваших публицистических работах.

Желаем Вам дальнейших научных достижений, крепкого здоровья, счастья Вам и Вашим близким, и долгих лет жизни на благо отечественной и мировой науки.

Ю. С. Осипов, Л.Д. Фаддеев 